\title{
Petrographic Garden in Moryń - a new geotouristic attraction in western Poland
}

\author{
Maria Górska-Zabielska1, Ryszard Dobracki² \\ ${ }^{1}$ Institute of Geography, Jan Kochanowski University, Kielce, Poland; maria.gorska-zabielska@ujk.edu.pl \\ ${ }^{2}$ Polish Geological Institute - Polish Research Institute, Pomeranian Department in Szczecin, Poland
}

\begin{abstract}
A new petrographic garden was established in 2012 in Moryń, north-western Poland. Thirty five erratics, derived from adjacent till moraines, witness local geological heritage and form a new geotouristic attraction. Together with other geovalues of this region, the petrographic garden is a cornerstone of the Polish-German geopark "Glacial Land over the Odra River" (Ger. Geopark Eiszeitland am Oderrand).
\end{abstract}

Key words: erratic, petrographic garden, geodiversity, geological heritage, geotourism, north-western Poland

\section{Introduction}

The geological heritage of Pojezierze Myśliborskie (the Myślibórz Lakeland) is comprised first of all of postglacial forms and deposits related to the last Scandinavian ice-sheet of the Pomerania stage in this area $\left(15,2{ }^{14} \mathrm{C} \mathrm{Ka}\right.$, Kozarski 1986, 1988, Marks 2002, 16,2 ka BP, Kozarski 1995, 14,8 $\pm 0,4{ }^{10} \mathrm{Be}$ ka, Rinterknecht et al. 2005, Marks 2011). The relief (Fig. 1) forms consist of:

1) a series of end moraines developed in the shape of an arch which marks the reach of the Odra lobe i.e. the outlet glacier of the Scandinavian ice-sheet (Keilhack 1897, 1898, 1899, cf. Korn 1915, Kozarski 1965 a, b, Roszko 1968, Karczewski 1968, 1969, 1995, Galon 1972, Karczewski, Roszko 1972, Kliewe, Kozarski 1979, Liedtke 1981, Bremer 1994), including

2) depositional end moraines well developed in the southern and south-eastern part of the Odra lobe (Kozarski 1965 a, 1978, 1981, Karczewski 1968, 1969 , Kliewe and Kozarski 1979, Piotrowski 1991 a). Between the end moraines of the maximum advance and two recessive substages (Angermünde-Chojna and Penkuner-Mielęcin)

3) an undulating, flat in places, till plain occurs in the hinterland of the end-morainic zone as well as

4) outwash areas (eg. the outwash plain of the river Myśla valley) or outwash-kame areas originating at the equable balance of masses of ice (Karczewski 1995, 1996, Mojski 1977 a, b). In the diversified relief of the areas southward of Moryń, the Moryń outwash plain should also be noticed (Kozarski 1965 a, Mojski 1977 a, b, Piotrowski 1991 a, b, c, 1999 b), which, being a part of the Równina Gorzowska (the Gorzów Plain), constitutes the western part of the foreland of the glaciomarginal zone of the Pomeranian stage. In

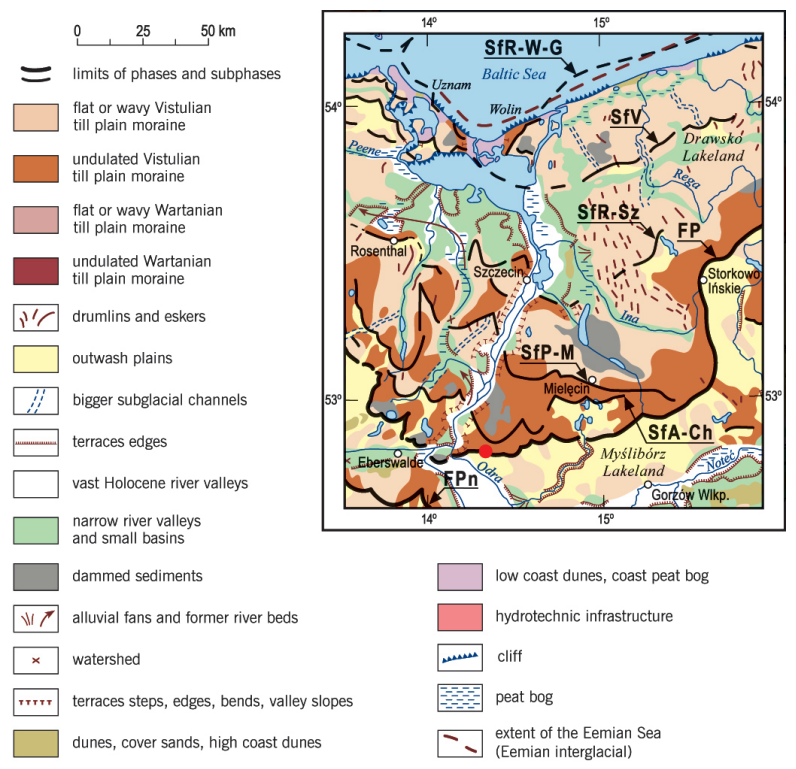

Fig. 1. Location of Moryń (red dot) on the geomorphological map in the border zone between north-western Poland and north-eastern Germany (based upon Liedtke 1981, Bremer 1994) 
the transitional zone between the end moraine and the outwash there is

5) a transitional cone (Pisarska-Jamroży 2006, 2008 a, b).

To the concave forms of Pojezierze Myśliborskie belong the main subglacial channels, which are characteristic of the diversified depth of cuts and of the N-S and NW-SE pattern; the channels reflecting the pattern of faults in the under-Quaternary bedrock (Piotrowski 1996, 1999 a).

In the lithological respect, the hummocks of Pojezierze Myśliborskie consist of a boulder cluster (Kozarski 1965 a, 1981 - an end moraine rewashed sensu Klimaszewski 1981), which retreats in places to the postglacial sandy and gravel material. Also Piotrowski (1991a) indicates the occurrence of boulders in the depositional morainic hills. Glacial tills of the Pomeranian stage appear universally in the areas of the plateaux, whereas sporadically in the roof of the glaciomarginal forms. Mojski (1977 a, b) describes such till as heavily sandy. In places it is indistinguishable from the loamy sands. Transitional cones, though, are built of deposits of various fractions: glacial till, sand, gravel and glaciofluvial boulders.

The boulder cluster, in the form of the well-lathed rock material, reveals itself within the limits of Pojezierze Myśliborskie in some mines of gravel aggregate in Moryń (Polbeton) and other areas in the vicinity, for example in Skotnica and in Chełm Górny (Lafarge). Big erratics occur also in the fields and forests near Dolsk, Gądno and Stare Objezierze.

Extraction of boulders of the surface layer of deposits or their appearance quite on the surface of the ground may suggest that they were transported by the last Scandinavian ice-sheet in this area not earlier than during the Pomeranian stage of the Upper Pleni Vistulian.

\section{Geodiversity of the region}

The aforementioned diversified forms and deposits are signs of the substantial geodiversity of the region which, in the times of searching for new tourist offers, constitutes a significant geotourist capacity. If the geodiversity receives appropriate promotion, certainly it will become attractive for alternative tourists e.g. geotourists who seek not just an interesting, extraordinary spot to take a rest but also competent information about watched (geo)resources and (geo)values. With regard to larger exploitation of such an area and the increased anthropopression which follows, pains should be taken to ensure that the area of geodiversity is subjected to an attentive care to preserve it for the future in the least devastated and altered condition possible.

The equally rich geological heritage in the eastern Brandenburg has been protected since 2005 under the terms of the GeoPark Eiszeitland am Oderrand. On the Polish bank of the Odra river, the Office for the City of Moryń together with the National Geological Institute of the National Research Institute, the Pomeranian Department in Szczecin, also strive at establishing such a form of protection. The Geopark Glacial Land over the Odra River (Pol. Kraina Lodowcowa nad Odra) in Poland is to embrace an area of the south-western part of the West Pomerania Province and along with its counterpart in Germany is designated for constituting a cross-border geopark. At present many studies into geosites are appearing which are to create the range of spots (a kind of thematic network) connected with the advance, stay and retreat of the last ice-sheet in this area.

The manifestation of the ice-sheet activity in this area includes the occurrence of erratics. They are dragged around across the fields and forests of the region and occur in more concentrated forms at the outlet of the former glacial gateways in Golice, Moryń and Chełm.

\section{Petrographic garden}

On the initiative of Ryszard Dobracki from the Pomeranian Department of the National Geological Institute of the National Research Institute in Szczecin as well as of Jan Maranda, the mayor of the City and Commune of Moryń, together with the content-related cooperation of the authoress, several dozens of boulders from the vicinities of Moryń were transported to the city centre in 2011. In 2012 a petrographic garden was open to the public. Today it co-creates the Moryń project Stone in Nature, History and Culture (Pol. Kamień w naturze, historii i kulturze). Together with other already existing objects constituting geovalues of the town and region (e.g. the permanent exposition called the Pleistocene Star Avenue) it creates the initial Polish part of the cross-border Geopark Glacial Land over the Odra River (Pol. Kraina Lodowcowa nad Odra). The Geopark objective is first of all the promotion of geological and scientific values, but of course the aspect of the economic development of the region, to a substantial extent dependent on some attractive forms of geotouristic development, is also of great importance. The petrographic garden situated in the city centre plays an unquestionably aesthetic role as it embellishes the square in the neighbourhood of the fifteenth-century city walls (Fig. 2, 3).

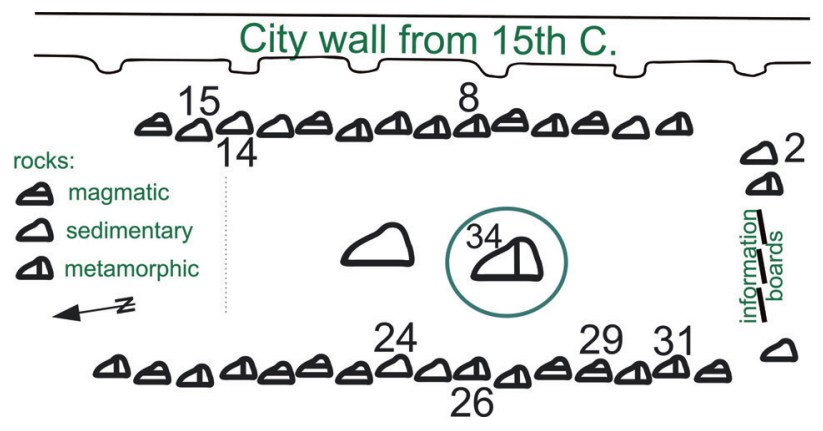

Fig. 2. Petrographic garden in Moryń. Thirty five erratics, located at the foot of the city wall from $15^{\text {th }}$ century, are accompanied by three information boards 


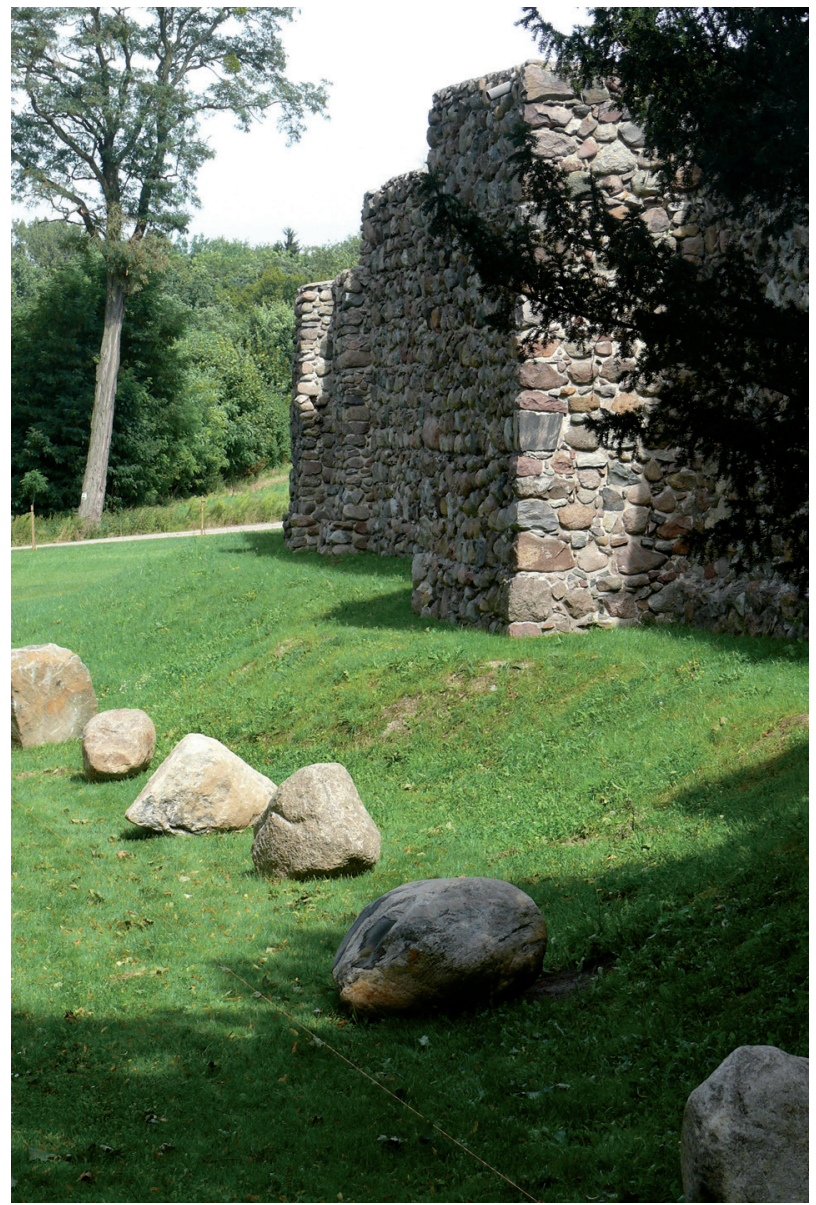

Fig. 3. Fragment of the petrographic garden at the foot of the fifteenth-century city walls in Moryń

The location of the boulder collection in Moryń is not accidental. It is here where the centre of management of the future geopark Kraina Lodowcowa nad Odra has its seat (Dobracki 2011). A tourist, having visited the permanent exhibition of the geopark presented in the building next to the City Office, may take a two-minute-long walk westward along Żeromski street, reach the city gate and, behind the gate, to the right at the foot of the city walls (Fig. 3), can notice 35 erratics (another ten boulders are just being prepared for determination and description), arranged along two parallel lines. In the middle of the collection are two bigger erratics; one placed close to the flower bed (Fig. 2).

The vast majority of erratics in the Petrographic Garden in Moryń do not exceed $0,5 \mathrm{~m}^{3}$ in volume and weigh less than 1 ton. The weight of only five boulders fits within 4-7 tons, and their volume is from 1,47 to $2,6 \mathrm{~m}^{3}$. However, it was not the gauges that were primarily taken into consideration when a boulder was being classified as appropriate for the exposition in the Garden. The creators of this collection intended first of all to present all the petrographic types of rocks. Hence, both the magmatic - plutonic rocks and sedimentary rocks as well as metamorphic rocks were gathered (Table 1).

Six indicator erratics, meaning those rocks of known Scandinavian provenance, can be found among the errat-

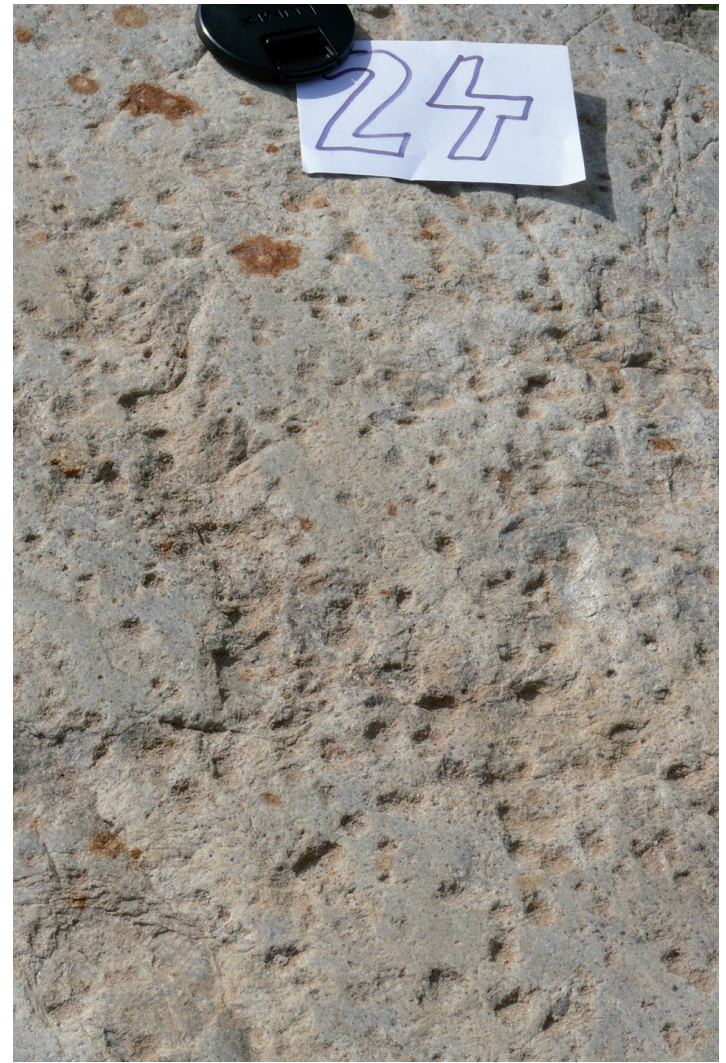

Fig. 4. Tafoni - small cave-like features of honeycomb weathering - on the surface of Jotnian sandstone (boulder No 24)

ics (Czubla et al. 2006, Górska-Zabielska 2007, 2008 a, b). These are: Småland granites (boulders No 5, 18 and 35) from the south-eastern part of Sweden, from Värmland: Filipstad granite (No 21) and Graverfors granite (No 23) as well as Blekinge-Karlshamn granite (No 28).

Eight further boulders are erratics of limited indicator value; therefore they have a supported character (so called Leitgeschiebe, Vinx 1993). The parent area in which they originate is characteristic of a large area (Lower Paleozoic limestones) and also a few outcrops in Scandinavia (Jotnian sandstones). These are the following boulders: Lower Paleozoic limestones No: 2, 4, 14 and Jotnian sandstones No: 13, 15, 24 (Fig. 4), 25, 33.

Boulders gathered in the Petrographic Garden in Moryń were also classified on the basis of elements of their relief, which they acquired either already during their glacial transport, or after their deposition. Therefore, boulders with both characteristic glacial polish (8) and with glacial striae $(14,24,25,29)$ can be found in the Garden too. Icesmoothed boulder No 34 (Fig. 5) resembles a sacrificial table. Boulders which were transported in the high-energy environment, so most probably in the subglacial tunnels, obtained a typically rounded shape (5 (Fig. 6), 6, 15, 18, 19, 21). Erratics No 30, 32, 35, due to their scarcely lathed rims, must have been in this environment for a shorter time or the energy of the water flowing around them was smaller. Some boulders are weathered $(9,10)$. The effect of exfoliation can be observed on the surface of boulder 22, while tafoni - small cave-like features of honeycomb weathering - are evident on boulder No 24 (here: on the 


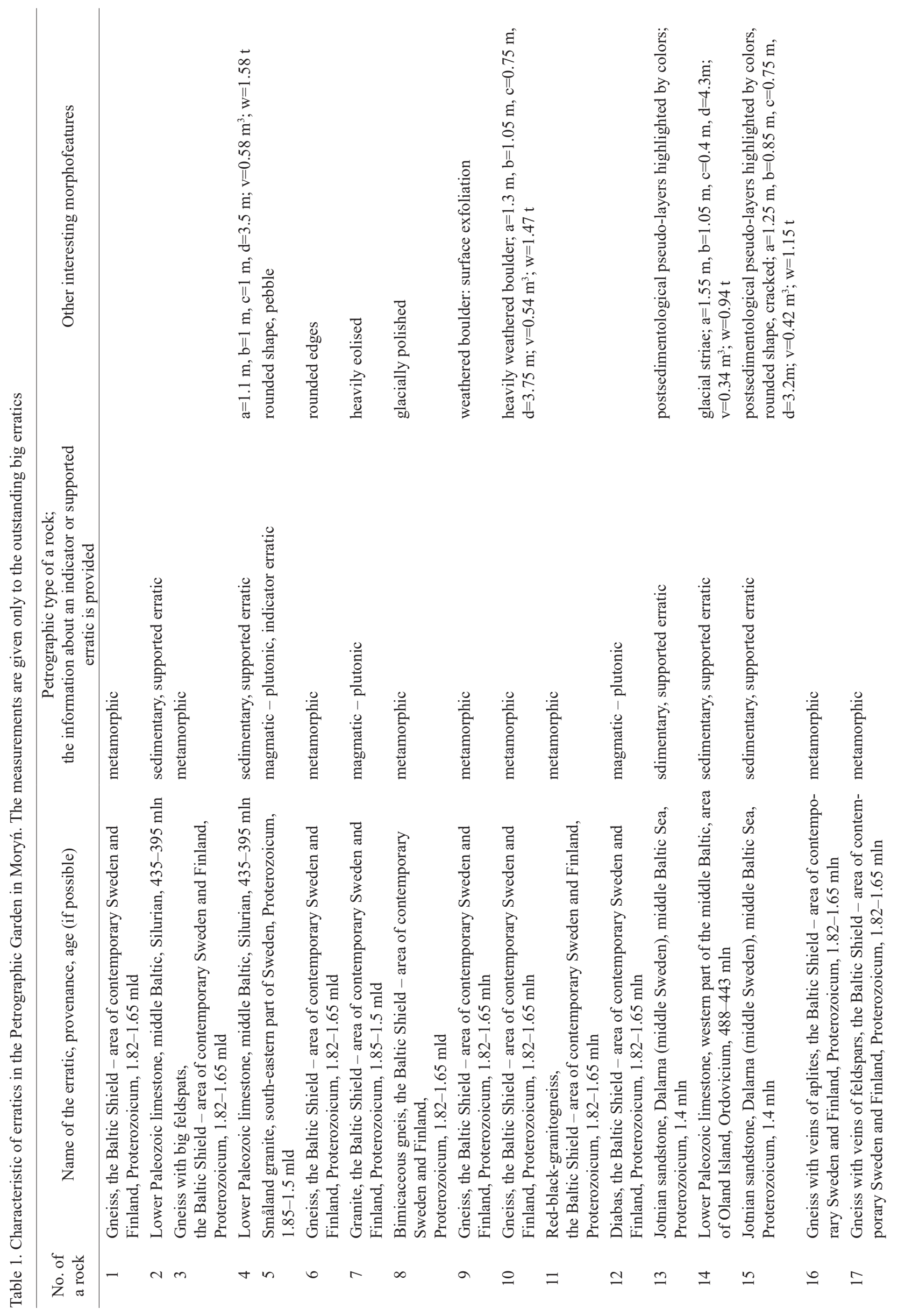




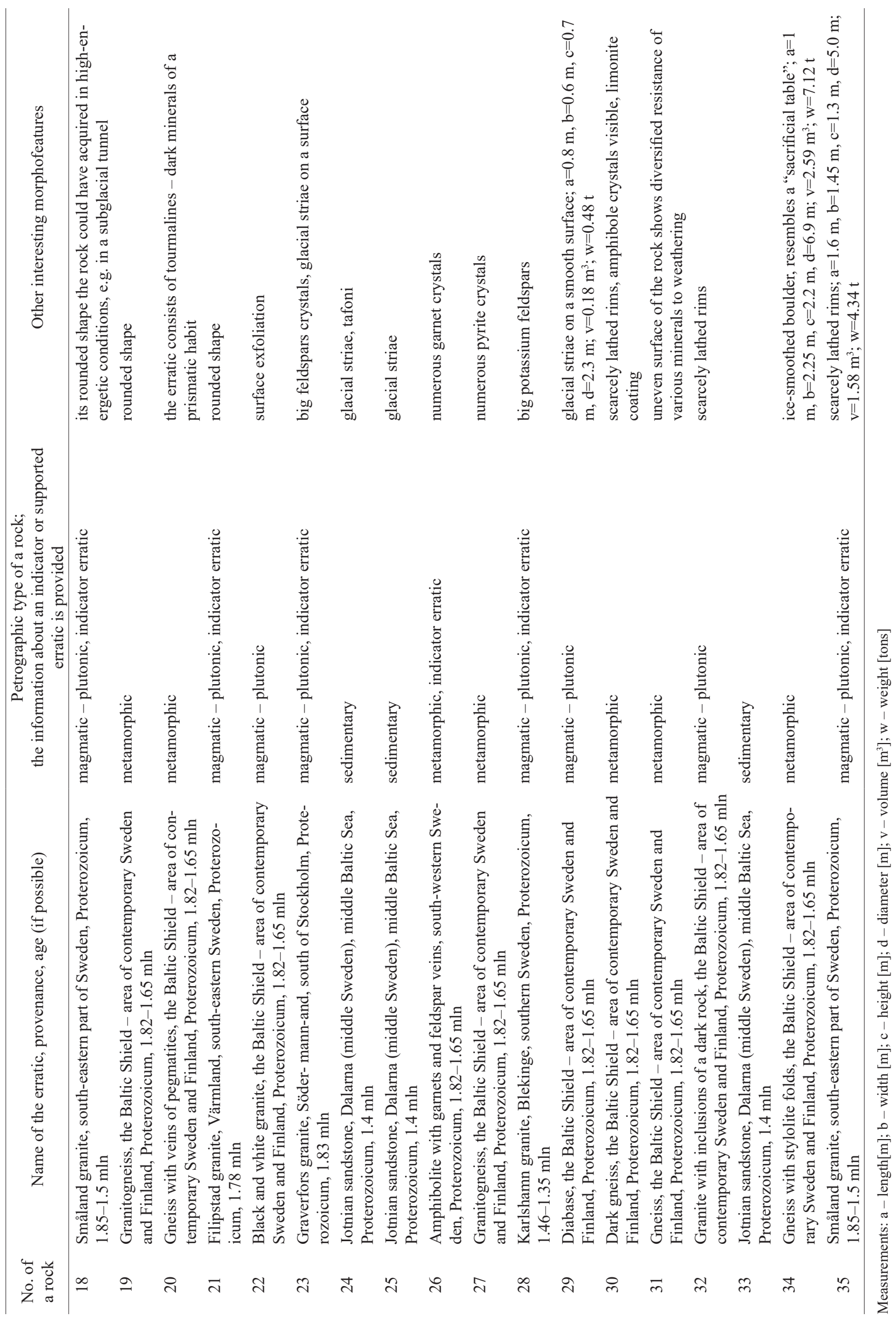




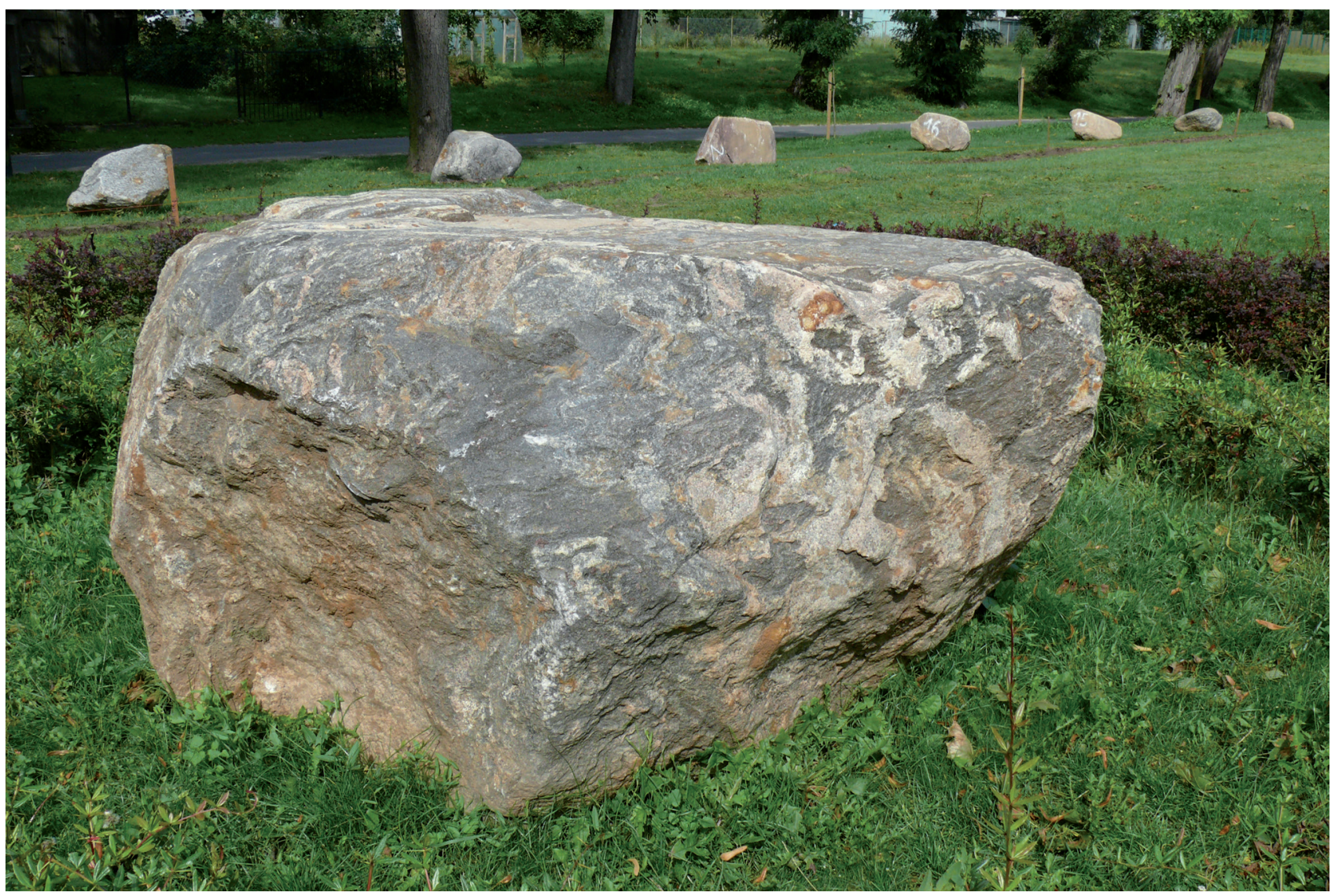

Fig. 5. Boulder No 34 in the petrographic garden in Moryń resembles a sacrificial table in shape; the boulder is a gneiss with beautifully developed stylolite folds - visible in the photograph

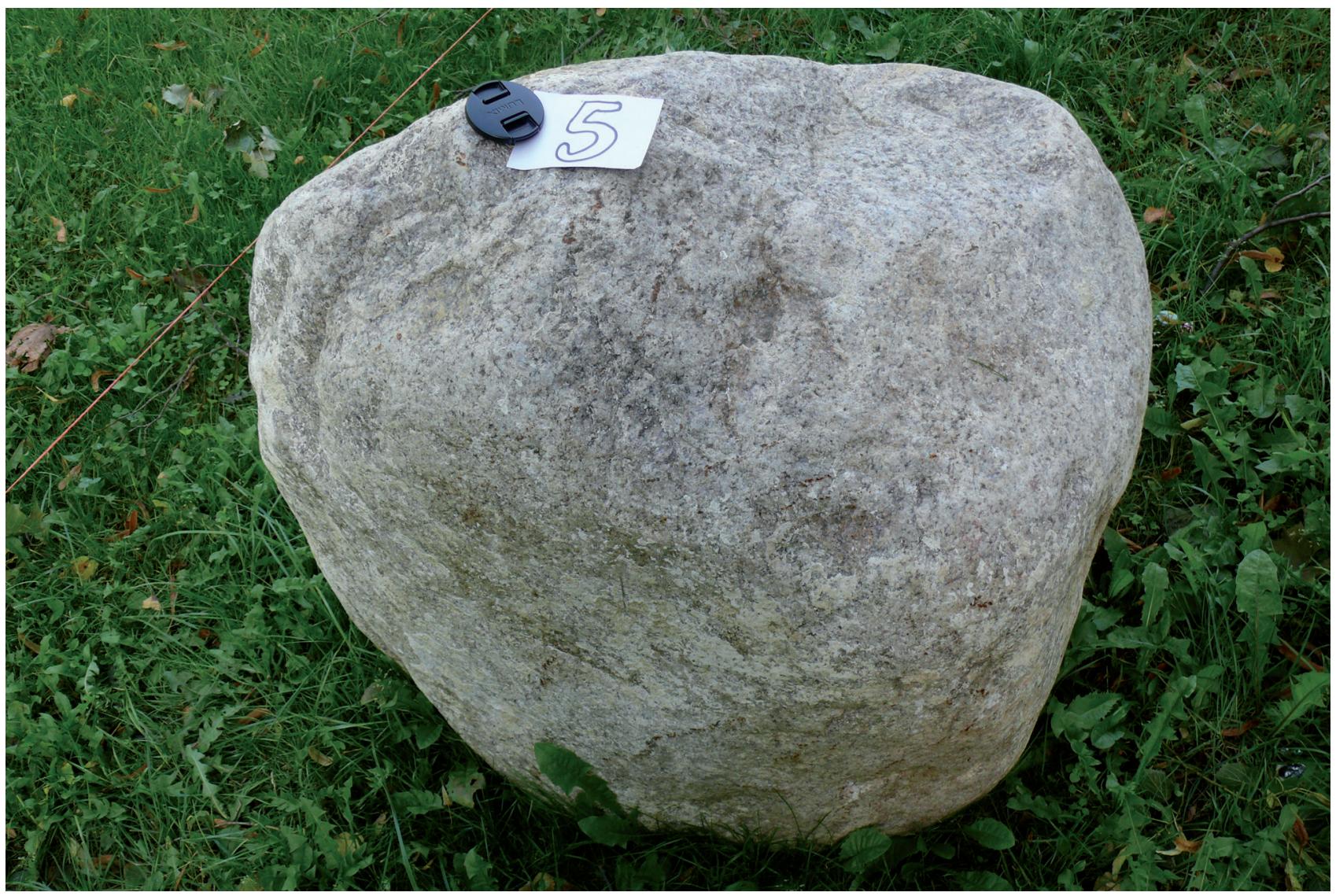

Fig. 6. Boulder No 5 - a pebble - gained its shape in the high-energy environment, most probably in the subglacial tunnel 
surface of the Jotnian sandstone; Fig. 4). The surface of the erratic No 7 must have been subjected for a longer time to the windy-sand stream as it is heavily eolised.

The erratics collection is accompanied by three large information boards: 1. Minerals and Rocks, 2. Erratics' Mother Country, 3. Migration of Boulders; and thanks to these a (geo)tourist may get to know how these erratics found their way to Moryń, what petrographic types they represent and what environment caused the relief elements visible on their surfaces today.

\section{Conclusions}

The Petrographic Garden in Moryń consists of 35 representatives of erratics deposited in the area of Pojezierze Myśliborskie during the advance of the last Scandinavian ice-sheet, that is, during the Pomeranian stage of the Vistulian glaciation. The collection comprises examples of all the petrographic types of rocks, meaning: magmatic, sedimentary and metamorphic rocks. Among them individual examples of indicator erratics occur, which originated in Värmland in central Sweden ( 2 boulders), in Småland in the south-eastern part of Sweden (3 boulders) and in Blekinge in southern Sweden (1 boulder).

The lapidarium in Moryń is a part of the aforementioned bigger Project Stone in Nature, History and Culture (Pol. Kamień w naturze, historii i kulturze), aimed at the promotion of the rich geological heritage of the region. By virtue of the fact that Pojezierze Myśliborskie is characteristic of an outstanding geodiversity, the Geopark Glacial Land over the Odra River (Pol. Kraina Lodowcowa nad Odra) is going to be established. Similarly, the remarkable geovalues present are typical of Uckermark in eastern Brandenburg; thus, since 2005, it has been the location of GeoPark Eiszeitland am Oderrand. Both forms of protection of inanimate nature are supposed to create a common cross-border geopark in the future. The geologic heritage of the Odra lobe (Górska-Zabielska 2008a) will become a precious attraction in the geotouristic offer of both countries.

For the time being, in the preparation period, analyses and studies having in view showing the above-average values of abiotic objects are being carried out. This article is but one of the signs of the above process.

\section{References}

Bremer F., 1994. Geologische Karte von Mecklenburg-Vorpommern. Übersichtskarte 1:500 000 - Oberfläche. Geologisches Landesamt MV, Schwerin

Czubla P., Gałązka D., Górska M., 2006. Eratyki przewodnie w glinach morenowych Polski. Przegląd Geologiczny 54(4): 352-362.

Dobracki R., 2011. Geopark epoki lodowca nad brzegami Odry - centrum Moryń. Konferencja Geoparki - Georóżnorodność - Geoturystyka, Instytut Nauk o Ziemi UMCS, Lublin, 6-8.06.2011: 18-19.

Galon R., 1972. Pojezierze Pomorskie i przyległe wysoczyzny jeziorne. In: R.Galon (ed.), Geomorfologia Polski, vol. 2: 129-156.
Górska-Zabielska M., 2007. Eratyki skandynawskie - metodyka i interpretacja. In: E. Mycielska-Dowgiałło, J. Rutkowski (eds.), Badania cech teksturalnych osadów czwartorzędowych i wybrane metody oznaczania ich wieku, Wyd. SWPR, Warszawa: 75-82.

Górska-Zabielska M., 2008a. Fennoskandzkie obszary alimentacyjne osadów akumulacji glacjalnej i glacjofluwialnej lobu Odry. Wydawnictwo Naukowe UAM, Geografia 78: 330 pp.

Górska-Zabielska M., 2008b. Obszary macierzyste skandynawskich eratyków przewodnich osadów ostatniego zlodowacenia północno-zachodniej Polski i północno-wschodnich Niemiec. Geologos 14(2): 177-194.

Karczewski A., Roszko L., 1972. Grundriß des Rückzuges des Inlandeises der letzten Vereisung zwischen der Oder und der Weichsel mit besonderer Berücksichtigung des Oderlobus. Wissenschaftlicher Zeitschrift der Ernst-Moritz-Arndt Universität Greifswald 1: 27-29.

Karczewski A., 1968. Wpływ recesji lobu Odry na powstanie i rozwój sieci dolinnej Pojezierza Myśliborskiego i Niziny Szczecińskiej. Poznańskie Towarzystwo Przyjaciół Nauk, Prace Komisji Geograficzno-Geologicznej 8(3): 105 pp.

Karczewski A., 1969. Types and stages of deglaciation in areas of the Odra Lobe in Western Pomerania. Geographia Polonica 17: 189-196.

Karczewski A., 1995. Modele formowania się strefy marginalnej fazy pomorskiej na Pomorzu Zachodnim i Środkowym. Poznańskie Towarzystwo Przyjaciół Nauk, Sprawozdania Wydziału Matematyczno-Przyrodniczego 109 (1991-1994), 1: 67-68.

Karczewski A., 1996. Zróżnicowanie morfo- i litogenetyczne fazy pomorskiej na obszarze Pomorza Zachodniego i Środkowego. In: A.Kostrzewski (ed.), Geneza, Litologia i Stratygrafia Utworów Czwartorzędowych. Geografia 57: 137-154.

Keilhack K., 1897. Die Drumlinlandschaft in Norddeutschland. Jahrbuch der Königlich Preußischen Geologischen Landesanstalt 17: 163-188.

Keilhack K., 1899. Die Stillstandslagen des letzten Inlandeises und die hydrographische Entwicklung des Pommerschen Küstengebietes. Jahrbuch der Preußischen Geologischen Landesanstalt 19: 90-152.

Kliewe H., Kozarski S., 1979. Zur Verknüpfung von Marginalzonen im Bereich des Oderlobus. Acta Universitatis Nicolai Copernici, Geografia 14(46): 21-30.

Klimaszewski M., 1981. Geomorfologia. PWN, Warszawa, 1063 pp.

Korn J., 1915. Untersuchungen in der Glaziallandschaft östlich vom Odergletscher. Jahrbuch der Königlich Preussischen Geologischen Landesanstalt 36: 396-420.

Kozarski S., 1965 a. Zagadnienie drogi odpływu wód pradolinnych z zachodniej części Pradoliny Noteci-Warty. Poznańskie Towarzystwo Przyjaciół Nauk, Prace Komisji Geograficzno-Geologicznej 5(1): 97 pp.

Kozarski S., 1965 b. Differential Baltic ice-stream activity on the example of the Odra Lobe. Geographia Polonica 6: 29-34.

Kozarski S., 1978. Lithologie und Genese der Endmoränen im Gebiet der skandinavischen Vereisungen. Schriftenreihe für Geologische Wissenschaften 9: 179-200.

Kozarski S., 1981. Ablation end moraines in western Pomerania, NW Poland. Geografiska Annaler 63(3-4): 169-174.

Kozarski S., 1986. Skale czasu a rytm zdarzeń geomorfologicznych vistulianu na Niżu Polskim. Czasopismo Geograficzne 57: 247-270.

Kozarski S., 1988. Time and dynamics of the Last Scandinavian Ice-Sheet retreat from northwestern Poland. Geographia Polonica 55: 91-101.

Kozarski S., 1995. Deglacjacja północno-zachodniej Polski: warunki i transformacja geosystemu ( 20 Ka „10 Ka BP). IGiPZ PAN, Dokumentacja Geograficzna 1: $82 \mathrm{pp}$.

Liedtke H., 1981. Die nordischen Vereisungen in Mitteleuropa. Forschungen zur deutschen Landeskunde. Band 204: 308 pp.

Marks L., 2002. Last Glacial Maximum in Poland. Quaternary Science Reviews 21: 103-110.

Marks L., 2011. Quaternary Glaciations in Poland. Developments in Quaternary Science 15: 299-303.

Mojski J.E., 1977a. Budowa geologiczna osadów plejstoceńskich w obszarze centralnej części lobu Odry. Kwartalnik Geologiczny 21(2): 370-371.

Mojski J.E. (ed.), 1977b. Objaśnienia do Mapy geologicznej Polski 1:200 000, ark. Pyrzyce, PIG. Wydawnictwa Geologiczne, Warszawa. 
Piotrowski A., 1991a. Objaśnienia do Szczegółowej mapy geologicznej Polski 1:50 000, ark. Cedynia (343). PIG, Warszawa.

Piotrowski A., 1991b. Objaśnienia do Szczegółowej mapy geologicznej Polski 1:50 000, ark. Chojna (344). PIG, Warszawa.

Piotrowski A., 1991c. Rzeźba i budowa geologiczna sandru moryńskiego. Kwartalnik Geologiczny 35(4): 530-531.

Piotrowski A., 1996. Szczegółowa Mapa Geologiczna Polski 1:50 000, ark. Trzcińsko Zdrój (345). PIG, Warszawa.

Piotrowski A., 1999a. Wpływ zróżnicowanego obciążenia strefy krawędziowej lądolodu na migrację soli. Przegląd Geologiczny 47(11): 1016-1020.

Piotrowski A., 1999b. Objaśnienia do Szczegółowej mapy geologicznej Polski 1:50 000, ark. Stara Rudnica (383) i Mieszkowice (384). PIG, Warszawa.

Pisarska-Jamroży M., 2006. Transitional deposits between end-moraine and sandur plain in the Pomeranian glaciomarginal zone of NW Po- land: a missing component of ice-contact sedimentary models. Boreas 35: $126-141$

Pisarska-Jamroży M., 2008. Mechanizmy depozycji w strefie glacimarginalnej zlodowacenia Wisły. Studium sedymentologiczne z Pomorza Zachodniego i Jutlandii. UKW, Bydgoszcz: 163 pp.

Pisarska-Jamroży M., 2008. Zonation of glaciomarginal environment inferred from Pleistocene deposits of Mysliborz Lakeland, NW Poland. Geografiska Annaler 90A: 237-249.

Rinterknecht V. R., Marks L., Piotrowski J. A., Raisbeck G. M., Yiou F., Brook E. J., Clark P. U., 2005. Cosmogenic ${ }^{10}$ Be ages on the Pomeranian Moraine, Poland. Boreas 34: 186-191.

Roszko L., 1968. Recesja ostatniego lądolodu z terenu Polski. Prace Geograficzne Instytutu Geografii Polskiej Akademii Nauk 74: 65100.

Vinx R., 1993. Hochauflösende Rekonstruktion von Eistransportwegen: Die „Leitserienme-thode“. Archiv für Geschiebekunde 1(11): 625-640. 